\title{
Venetoclax-rezisztencia krónikus lymphocytás leukémiában
}

\author{
László Tamás ${ }^{\circledR}$, Kotmayer Lili, Alpár Donát, Bödör Csaba \\ HCEMM-SE Molekuláris Onkohematológiai Kutatócsoport, \\ I. sz. Patológiai és Kísérleti Rákkutató Intézet, Semmelweis Egyetem, Budapest
}

\begin{abstract}
Bevezetés: A krónikus lymphocytás leukémia (CLL) a nyugati világban leggyakrabban előforduló felnőttkori hematológiai malignitás, amely változatos klinikai lefolyással, valamint jelentős citogenetikai és molekuláris heterogenitással bír. A CLL kezelésében alkalmazott kemo-immunoterápiák mellett az elmúlt években megjelent célzott terápiák, mint a Bruton-féle tirozin kináz (BTK) gátló ibrutinib és acalabrutinib, a foszfatidilinozitol-3-kináz gátló idelalisib vagy az antiapoptotikus hatású B sejtes lymphoma 2 (B cell lymphoma 2, BCL2) fehérje gátló venetoclax forradalmasította a kedvezőtlen prognózisú újonnan diagnosztizált és refrakter/relabáló $(\mathrm{R} / \mathrm{R})$ betegek kezelését. A venetoclax egy nagy szelektivitással rendelkező, orálisan adható BCL2-inhibitor, amely jelentős sikerrel alkalmazható CLL-ben, beleértve a TP53 aberrációval rendelkező betegeket is. A meggyőző klinikai eredmények ellenére a betegek egy részében a terápia során rezisztencia alakul ki, amelynek pontos háttérmechanizmusa jelenleg is aktív kutatás tárgyát képezi. Közleményünkben ismertetjük a BCL2 apoptózist szabályozó fehérje CLL-ben betöltött szerepét, a venetoclaxnak a BCL2 fehérjére, valamint a sejtmetabolizmusra gyakorolt hatását. Ezen felül bemutatjuk a venetoclax-rezisztencia hátterében álló potenciális molekuláris mechanizmusokat, a rezisztenciával asszociált, újonnan leírt genetikai mutációkat, valamint a genetikai elváltozások kimutatására és követésére szolgáló vizsgálatok előnyeit és határait. A közlemény végén röviden kitérünk a venetoclax-rezisztencia megjelenését követő terápiás kihívásokra és kezelési lehetőségekre is.
\end{abstract}

Kulcsszavak: krónikus lymphocytás leukémia, venetoclax, terápiás rezisztencia, BCL2

\section{Venetoclax resistance in chronic lymphocytic leukemia}

Introduction: Chronic lymphocytic leukemia (CLL) is the most common type of leukemia in the Western world. Besides the widely used chemo-immunotherapeutic approaches, in the last couple of years, new targeted therapies have become available, such as the Bruton tyrosine kinase inhibitors ibrutinib and acalabrutinib, the phosphoinositide 3-kinase inhibitor idelalisib or the antiapoptotic B-cell lymphoma 2 (BCL2) inhibitor venetoclax, which have revolutionized the treatment of both treatment naïve and relapsed/refractory $(\mathrm{R} / \mathrm{R})$ patients. Venetoclax is a highly selective, oral BCL2-inhibitor, successfully applied in the treatment of patients harboring TP53 aberrations or failing on prior lines of therapy. Despite the promising clinical results, a subset of venetoclax treated patients experience resistance. The underlying mechanisms of venetoclax resistance are still intensively studied. In our review we provide an overview of the role of BCL2 apoptosis regulator protein in CLL, the effect of venetoclax on the BCL2 protein and cellular metabolism. Moreover, we aim to summarize the possible mechanisms of venetoclax resistance, with special emphasis on recently described genetic aberrations along with the advantages and limitations of molecular techniques commonly applied for the detection and monitoring of disease associated genetic alterations. Finally, we briefly discuss the therapeutic challenges and treatment options to overcome venetoclax resistance.

Keywords: chronic lymphocytic leukemia, venetoclax, therapeutic resistance, BCL2

(Beérkezett: 2021. október 29.; elfogadva: 2021. november 7.)

\footnotetext{
@ Levelezési cím: Dr. László Tamás, HCEMM-SE Molekuláris Onkohematológiai Kutatócsoport, I. sz. Patológiai és Kísérleti Rákkutató Intézet, Semmelweis Egyetem, 1085 Budapest, Üllői út 26.; Tel.: +36-1-215-7300;

E-mail: laszlo.tamas@stud.semmelweis.hu
} 


\section{Rövidítések}

AMP - adenozin monofoszfát (adenosine monophosphate); AMPK - adenozin monofoszfát aktiválta protein kináz (adenosine monophosphate activated protein kinase); ATF4 - aktiváló transzkripciós factor 4 (activating transcription factor 4); BAD - BCL-2 associated death promoter; BAK - BCL2-antagonist/ killer 1; BAX - Bcl-2-associated X protein; BCL2 - B-sejtes lymphoma 2 (B cell lymphoma 2); BCL-w - Bcl-2-like protein 2; BCL-xl - B-cell lymphoma-extra large; BH3 - Bcl-2 homology 3; BH3-only - Bcl-2 homology 3-only; BID - BH3 interacting-domain death agonist; BIK - BCL2-interacting killer; BIM - Bcl2-interacting mediator of cell death; BMF Bcl-2-modifying factor; BTK - Bruton-féle tirozin kináz (Bruton's tyrosine kinase); BTKi - Bruton-féle tirozin kináz inhibitor (Bruton's tyrosine kinase inhibitor); CAR-T - kiméra antigén receptor $\mathrm{T}$ (chimeric antigen receptor $\mathrm{T}$ ); CLL krónikus limfocitás leukémia (chronic lymphocytic leukemia); CLL-IPI - CLL Nemzetközi Prognosztikai Index (International Prognostic Index); COX - citokróm-c oxidáz (cytochrome-c oxidase); CR - komplett válasz (complete response); ddPCR - digitális droplet polimeráz láncreakció (droplet digital polymerase chain reaction); EMA - Európai Gyógyszerügynökség (European Medicines Agency); ETC - elektron transzport lánc (electron transport chain inhibitor); FC - fludarabin + ciklofoszfamid (fludarabine + cyclophosphamide); FCR - fludarabin + ciklofoszfamid + rituximab (fludarabine + cyclophosphamide + rituximab); FDA - Amerikai Élelmiszer- és Gyógyszerügynökség (U.S. Food and Drug Administration, FDA); HRK - Activator of apoptosis harakiri; ISR - integrált stressz válasz (integrated stress response); MAPK - mitogén aktiválta protein kináz (mitogen-activated protein kinase); MCL-1 - Induced myeloid leukemia cell differentiation protein; m-IGHV - mutált-IGHV (mutated-IGHV); MOMP - külső mitokondriális membrán permeabilizáció (mitochondrial outer membrane permeabilization); MRD - minimális reziduális betegség (minimal residual desease); NFAT - aktivált T-sejt nukleáris faktor (nuclear factor of activated T-cells); NGS - új-generációs szekvenálás (next generation sequencing); NOXA - Phorbol12-myristate-13-acetate-induced protein 1; OS - teljes túlélés (overall survival); OXPHOS - oxidatív foszforiláció (oxidative phosphorilation); PI3K/PKB - foszfoinozitid-3 kináz/protein kináz B (phosphoinositide-3-kinase/protein kinase B); PLCG2 - foszfolipáz C gamma 2 (phospholipase C gamma 2); PUMA p53 upregulated modulator of apoptosis; R/R CLL - refrakter/ relabáló CLL (relapsed/refractory CLL); VAF - variáns allél frekvencia (variant allele frequency)

\section{Bevezetés}

A krónikus lymphocytás leukémia (CLL) a nyugati országokban leggyakrabban előforduló leukémiatípus, amely CD5-CD19-CD23 pozitív érett B sejtek klonális proliferációjával jellemezhető a perifériás vérben, valamint a limfoid szervekben. Az újonnan diagnosztizált betegek megjelenésének gyakorisága évente kb. 4 eset 100000 före vetítve. A CLL jellemzően az idősebb populációt érintő, indolens lefolyású betegség, amely az esetek harmadában a betegek szoros követésén és monitorozásán kívül nem igényel egyéb teendőt (watch and wait stratégia), a betegek egy részében viszont gyors klinikai lefolyással és rossz prognózissal jár. A leukémiás sejtpopulációra jellemző a molekuláris és citogenetikai heterogenitás, amelynek átfogó feltérképezését az utóbbi évek újgenerációs szekvenálási (next generation sequencing, NGS) tanulmányai nagymértékben segítették [1]. A betegek között megfigyelhető molekuláris különbségek mellett a CLL egyénen belül is heterogenitást mutathat, melynek kialakulásában jelentős szerepet játszanak a különböző mikrokörnyezeti hatások [2], valamint a kezelés kapcsán megjelenő klonális evolúció [3].

$\mathrm{Az}$ elmúlt években a molekuláris diagnosztikában bekövetkezett robbanásszerü fejlődésnek köszönhetően több új prognosztikai faktor is előtérbe került. Ezek közül kiemelendő a TP53 és az immunoglobulin nehézlánc variabilis régió $(I G H V)$ mutációs státuszának meghatározása, valamint egyes kariotípus eltérések kromoszóma sávozással történő átfogó, vagy fluoreszcens in situ hibridizációval (FISH) való célzott vizsgálata [4-6]. Az utóbbi időben egyre nagyobb érdeklődés övezi a minimális reziduális betegség (minimal residual desease, MRD) áramlási citometriás módszereken vagy DNS szekvenáláson alapuló kimutatását, amely egy ígéretes, új prognosztikai marker lehet a közeljövőben [7]. Az új, célzott terápiák, valamint a számos, klinikai stádiumtól független prognosztikai marker megjelenésének következtében kialakult az igény egy, a Rai- [8] vagy Binet- [9] stádiumokat meghaladó részletességü prognosztikai osztályozás iránt [10]. A jelenleg használatban lévő legpontosabb rendszer a CLL Nemzetközi Prognosztikai Index (CLL International Prognostic Index, CLL-IPI), amely 5 független prognosztikai faktort vesz figyelembe: TP53 diszfunkció (17p deléció vagy TP53 mutáció), IGHV mutációs státusz [11], szérum $\beta 2$-mikroglobulin, Rai- vagy Binet-stádium, valamint az életkor [12].

A CLL kezelésében az első szisztémás kezelést a szteroidok, illetve az alkiláló ágensek bevezetése jelentette 1950-ben. A következő nagyobb lépést a nukleozid-analógok jelentették, elsősorban a fludarabin monoterápiaként, majd ciklofoszfamiddal kombinációban (FC) alkalmazva. Az igazi áttörést a kemo-immunoterápia megjelenése hozta el 2005-ben, amikor az FC kombinált kemoterápiát anti-CD20 antitesttel, rituximabbal egészítették ki (FCR). Az FCR volt az első olyan kezelési séma, amely tartós teljes remissziót (complete remission, CR) tudott létrehozni, valamint kedvezőbb teljes túlélést (overall survival, OS) biztosított az FC-terápiával szemben. Napjainkban a kemo-immunoterápia a fiatal, jó fizikai állapotban lévő betegeknél alkalmazott, elsősorban mutált immunoglobulin nehézlánc variabilis régió (m-IGHV, mutated IGHV) jelenléte esetén [12, 13]. A rossz prognózisú relabáló/refrakter CLL kezelésében forradalmi újítást hoztak a célzott terápiák, mint a 2014-ben bevezetésre került BTK gátló ibrutinib, vagy a 2019-ben megjelent BCL2 gátló venetoclax. A venetoclax a CLL első vonalában is alkalmazható, sőt a CLL14 tanulmány eredményei alapján, teljesen szokatlan módon a tanulmány célcsoportját - a nem fitt betegeket - figyelmen kívül hagyva, 
alkalmazását a fitt betegekben is javasolják [14]. Venetoclax kezelés esetén lehetőség van monoterápiára [15-18], valamint rituximabbal való kombinációra is [19, 20]. 2019ben az Amerikai Élelmiszer- és Gyógyszerügynökség (U.S. Food and Drug Administration, FDA), 2020-ban pedig az Európai Gyógyszerügynökség (European Medicines Agency, EMA) is elfogadta a venetoclax és obinutuzumab kombinációs terápiát, elsővonalbeli kezelésként krónikus lymphocytás leukémiában [21-23].

\section{Az intrinsic apoptotikus útvonal és a BCL2 protein szerepe}

A programozott sejthalál (apoptózis) a megváltozott genetikai állományú vagy irreverzibilisen károsodott sejtek gyulladás nélküli eliminációja által a tumorgenézis gátlá- sának kulcsfontosságú tényezője. Különböző sejtszintü hatások képesek apoptózist indukálni, mint a kemoterápiás ágensek, sugárzás vagy oxidatív stressz. A BCL2 a mitokondriális apoptotikus útvonalban központi szabályozó szerepet betöltő fehérje, amely túlzott expressziót mutat a CLL-es populációban [24-26]. A BCL2 az első leírt onkogén, amely onkogenikus hatását az apoptotikus útvonal gátlásán keresztül fejti ki, és nem a kontrollálatlan proliferáció-indukción keresztül [27]. A BCL2 családon belül az apoptózis effektor fehérjéit a BAX, illetve BAK képviselik, melyek aktivációja homo-oligomerizációhoz, a külső mitokondriális membrán permeabilizációjához (mitochondrial outer membrane permeabilization, „MOMP”), citokróm-c molekulák citoplazmába jutásához, végül a kaszpáz rendszer aktivációjához vezet (1. ábra). A folyamat elindításában jelentős szerepet töltenek be a csak BH3 homológ doménnel rendelkező fe-



1. ábra. Az intrinsic apoptotikus útvonal sematikus ábrázolása. Oxidatív stressz, sugárzás, kemoterápiás ágensek hatására a TP53 tumorszupresszor protein aktiválja a csak BH3 doménnel rendelkező (BH3-only) fehérjéket, amelyek aktiválják az apoptózis effektor proteinjeit (BAX, BAK). Ennek következtében a külső mitokondriális membrán permeabilizációja jön létre, és a citokróm-c cytosolba jutása beindítja a kaszpáz kaszkádrendszert, amely a sejtmag fragmentálódásához és apoptózishoz vezet. A krónikus lymphocytás leukémiában túlzott expressziót mutató BCL2 gátolja a folyamatot, így ideális terápiás célpontot képez. Az antiapoptotikus fehérjék legfontosabb gátlószereit az ábra jobb felső részén tüntettük fel 
hérjék („Bcl-2 homology 3-only”, „BH3-only”), amelyek proapoptotikus hatásukat a BAK/BAX aktivációján keresztül (aktivátor proteinek: BIM, BID) vagy az antiapoptotikus proteinek gátlásán keresztül (érzékenyítő proteinek: PUMA, NOXA, BAD, BIK, HRK, BMF) fejtik ki [28]. Ugyanakkor, ezek a fehérjék olyan tumorszuppreszszorok célpontjai, mint a TP53 [29]. Az antiapoptotikus proteinek (BCL2, BCL-xl, MCL1-BCL-w) az effektor, illetve a BH3-only fehérjék szekvesztrációján keresztül akadályozzák meg azok apoptózist kiváltó hatását (1. ábra) [30-32].

\section{A venetoclax hatásmechanizmusa}

A venetoclax (ABT-199) egy orálisan adagolható kismolekula, amely proapoptotikus hatását a BCL2 fehérje BH3 doménjéhez való szelektív kötődése által fejti ki. A BH3 mimetikum venetoclax magas affinitással kötődik a BCL2 fehérje BH3 kötőhelyéhez, így megfelelő koncentrációban képes leszorítani a BCL2 által szekvesztrált proapoptotikus hatású BH3-only fehérjéket (például BIM/BID). Ezáltal a felszabadult BH3-only fehérjék képesek aktiválni az intrinsic apoptotikus útvonal effektor molekuláit (BAX/BAK) vagy gátolni egyéb anti-apoptotikus fehérjéket. Strukturális szempontból a venetoclax BCL2 fehérjéhez való kötődésében fontos szerepet játszik a 103-as pozícióban elhelyezkedő aszpartát. A kötődés affinitása egy az aminosav és a venetoclax indol gyűrűje között létrejövő hidrogén-híd kötés függvénye [33]. Összességében a venetoclax beindítja, valamint visszaállítja az apoptózist a CLL sejtekben azáltal, hogy felszabadítja a proapoptotikus fehérjéket a BCL2 szekvesztrációja alól (2. ábra) [34, 35]. A venetoclax orális biohasznosulása, valamint viszonylag hosszú, 16-19 órás felezési ideje lehetővé teszi a kényelmes, napi egyszeri adagolást $[17,36]$.

A BCL2 család fehérjéi több apoptózistól független folyamatban is szerepet játszanak, elsősorban a sejtmetabolizmusban. A BCL2 túlzott expressziója növeli a COX aktivitást, ezáltal hozzájárul a mitokondriális légzési ciklus aktivitásához [37]. Ennek megfelelően Lagadinou és mtsai az oxidatív foszforiláció (OXPHOS) aktivitásának csökkenését mutatták ki BCL2 gátlás során, akut myeloid leukémiás sejtpopulációban [38]. A venetoclax szintén képes a sejtmetabolizmus befolyásolására, függetlenül az apoptózist indukáló hatásától [39-41]. Egy friss in vitro tanulmány alapján a venetoclax intrinsic apoptotikus útvonalban betöltött szerepétől függetlenül gátolja a mitokondriális oxidációt, valamint a citrátkört. Ennek a metabolikus folyamatok megváltozását eredményező off-target mechanizmusnak a hátterében az integrált stressz válasz (integrated stress response, ISR), valamint az ATF4 transzkripciós faktor szerepe igazolódott [41].

\section{A venetoclax-rezisztencia hátterében álló potenciális mechanizmusok}

A venetoclax elsővonalbeli, valamint $\mathrm{R} / \mathrm{R}$ CLL-ben történő alkalmazása során elért magas teljes terápiás válaszarányok ellenére $[17,19,22]$ a betegek egy részénél ve-

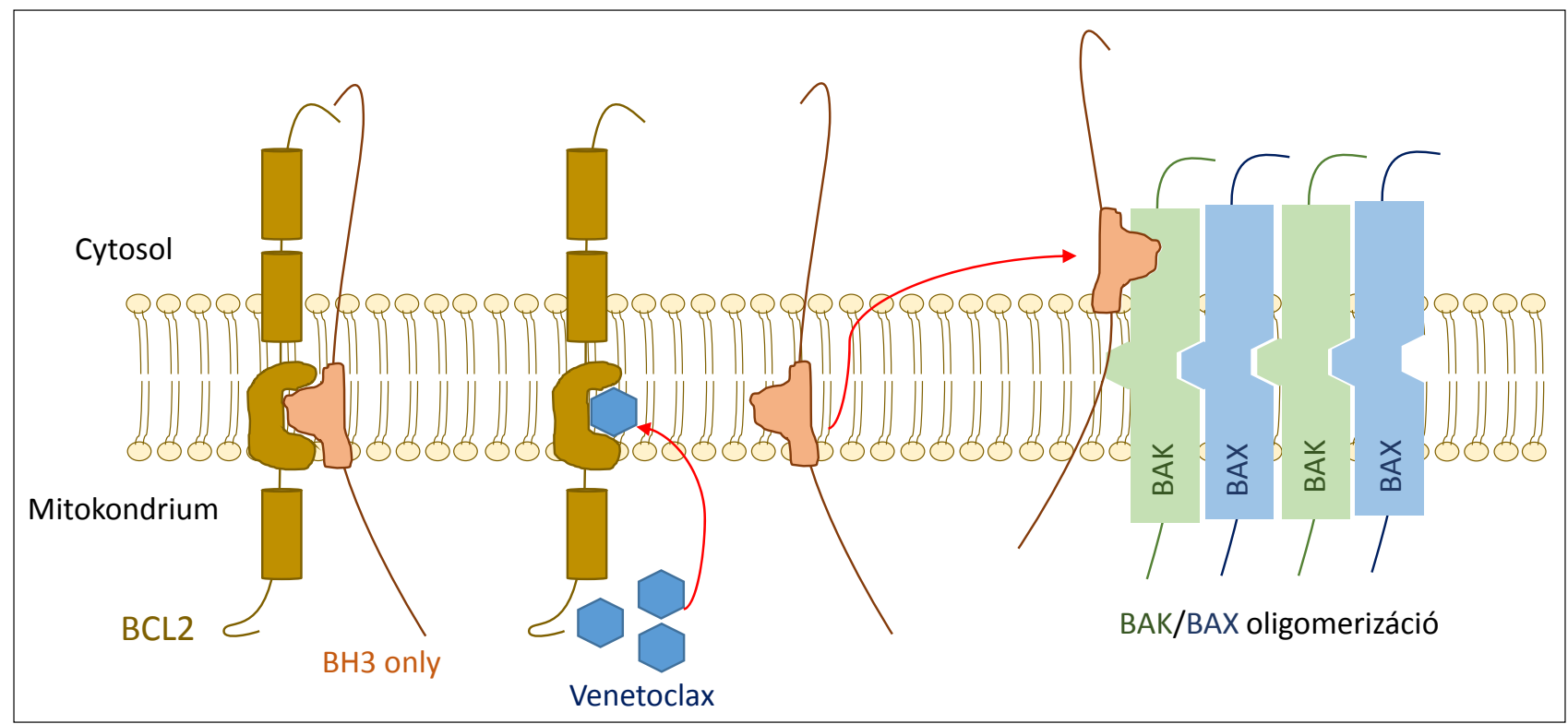

2. ábra. A venetoclax hatásmechanizmusa. CLL-ben a túlzott BCL2 expresszió meggátolja az effektor fehérjék aktiválását, a BH3-only proteinek szekvesztrációja által. A venetoclax, a BCL2 kompetitív antagonistája, ezáltal megfelelö koncentrációban képes leszorítani a BH3-only fehérjéket a BCL2 kötőhelyéről. Ennek hatására a felszabadult BH3-only proteinek aktiválják a BAX és BAK effektor fehérjéket. Az effektor fehérjék homo-oligomerizáción mennek keresztül, és létrehozzák a külső mitokondriális membrán permeabilizációt (MOMP). Rövidítések: BCL2 = B-sejtes limphoma 2 fehérje (B cell lymphoma 2 protein); BH3-only = csak BH3 homológ doménnel rendelkező fehérje (Bcl-2 homology 3-only); $\mathrm{BAX}=\mathrm{Bcl}$-2-associated $\mathrm{X}$ protein; BAK = BCL2-antagonist/killer 1 
netoclax-rezisztencia alakul ki. Bár a rezisztencia kialakulása nem számít túl gyakori jelenségnek, a kedvezőtlen klinikai lefolyás miatt vizsgálatának és áthidalásának igen nagy jelentősége van. A terápia sikertelenségének leggyakoribb oka szekunder rezisztencia, melynek létrejöttében szerepet játszó mechanizmusok jelenleg intenzív vizsgálatok tárgyát képezik. Az azonban feltételezhető, hogy a rezisztencia több, egymástól független folyamat klinikai manifesztációjaként is megjelenhet. Az intrinsic apoptotikus útvonal kulcsfontosságú pontjait figyelembe véve négy potenciális mechanizmus ismert/feltételezhető a venetoclax-rezisztencia hátterében: 1 . a $\mathrm{BAK} / \mathrm{BAX}$ proteinek hiánya, 2. TP53 diszfunkció, 3. BCL2-mutáció, valamint 4. egyéb a BCL2-től eltérő apoptózist gátló proteinek túlzott expressziója (1.ábra).

Az effektor fehérjék jelenléte nélkülözhetetlen a MOMP kialakulásához, szignifikáns hiányuk esetén az intrinsic apoptotikus útvonal teljes gátlása alakul ki. In vitro kísérletek során kimutatták, hogy a BAX-hiányos vagy nagyon alacsony BAX expressziót mutató venetoclax naiv sejtek a célzott terápia folyamán szelekciós előnyhöz jutnak, így potenciálisan felelősek lehetnek a rezisztencia kialakulásáért [42]. Az összes malignus hematológiai kórképet figyelembe véve a BAK és BAX fehérjék teljes hiánya irodalmi ritkaságnak számít, a jelenség hátterében álló mechanizmusok részleteikben nem ismertek [43].

A refrakter/relabáló CLL-ben szenvedő betegek csaknem 50\%-a rendelkezik kimutatható TP53 aberrációval (TP53 mutáció vagy 17p deléció), mely klonális evolúció nyomán jelenik meg, leggyakrabban az elsővonalbeli kemoterápia folyamán. A TP53 intrinsic apoptotikus jelátviteli útvonalban betöltött szerepe a $\mathrm{BH} 3$-only proteinek aktivációja celluláris stressz hatására, következésképp az apoptózis iniciálása. Anderson és mtsai 2016-ban in vitro kísérleteik során kimutatták, hogy a sejtek venetoclax indukálta apoptózissal szembeni érzékenysége nem függ TP53 aberráció jelenlététől. Ez az eredmény összhangban volt azon in vivo vizsgálataik során észlelt megfigyeléseikkel, miszerint a TP53 funkcióvesztés jelenléte nem befolyásolta a venetoclax perifériás limfocitózisra, csontvelő-infiltrációra, valamint a nyirokcsomók méretére gyakorolt hatását. Ezen in vitro és in vivo kísérleteik során arra a következtetésre jutottak, hogy a venetoclax a TP53 státusztól függetlenül képes a gyors apoptózisindukcióra [44].

Jelenlegi ismereteink alapján a venetoclax-rezisztencia kialakulásában az ibrutinibhez hasonlóan a célfehérjét kódoló gén pontmutációi meghatározó szerepet töltenek be. A mutációk konformációváltozást okoznak a fehérje térszerkezetében, csökkentve vagy megakadályozva a gyógyszer kötődését. Az első BCL2 régiót érintő pontmutációt Blombery és mtsai írták le. Tanulmányukban 15 venetoclax monoterápiában részesülő, progresszív CLLben szenvedő beteg közül 7 betegben mutatták ki a 101-es pozícióban levő glicin valinra történő cseréjét (G101V) [45]. In vitro tanulmányok kimutatták, hogy a G101V mutáció jelentősen csökkenti az érintett sejtek venetoclax terápiára adott válaszát, a venetoclax BCL2 fehérjéhez való kötődését és a mutáció jelenléte önmagában elégséges a venetoclax-rezisztencia kialakulásához [45, 46]. A 101-es pozícióban elhelyezkedő aminosav, a BCL2 fehérje $\mathrm{BH} 3$ kötő doménjét alkotó alfa hélix felépítésében vesz részt. A glicin-valin aminosavcsere következtében egy nagyobb térszerkezetű („bulky”) oldallánc keletkezik, amely konformációváltozáshoz vezet a BCL2 protein BH3 kötő doménjének szerkezetében, így gyengítve a venetoclax kötődési kapacitását [33, 45]. Annak ellenére, hogy a venetoclax-rezisztencia a jelenlegi limitált ismereteink alapján az esetek 50\%-ában G101V mutációval aszszociált [33, 45], az aberráció gyakran csupán alacsony, $1 \%$ körüli variáns allél frekvenciával (VAF) figyelhető meg, még progresszió idején is [47]. Az elmúlt években több, a G101V-től eltérő BCL2 mutációt is leírtak klinikai rezisztenciához társultan [33, 48, 49]. Ezek a további, gyakran szintén szubklonális BCL2 mutációk heterogén CLL-es sejtpopulációt hoznak létre. Érdekes megfigyelés, hogy legtöbb esetben a különböző mutációkat hordozó szubklónok valószínúsíthető együttes aránya sem éri el a CD5-CD19 pozitív CLL sejtpopuláció 50\%-át [48], amely egyéb, párhuzamos rezisztencia mechanizmusok jelenlétére enged következtetni. Egy 2020-as tanulmányban Lucas és mtsai 11 ibrutinib és venetoclax-rezisztenciával is rendelkező beteget vizsgálva arra a következtetésre jutottak, hogy ibrutinib elókezelt betegek esetén egy komplex, BTK, BCL2 és PLCG2 (foszfolipáz-c gamma 2) mutációkat is hordozó szubklonális mintázat figyelhető meg. Érdekes módon a klasszikus G101V mutáció kevésbé volt kimutatható a vizsgált populációban, elsősorban a különböző BTK pontmutációkkal rendelkező szubklónok dominanciája volt jellemző [49].

Egy másik potenciális venetoclax-rezisztenciát okozó mechanizmus az egyéb antiapoptotikus hatású BCL2 családba tartozó fehérjék túlzott kompenzációs expressziója [42, 50, 51]. Venetoclax kezelés hatására egy heterogén fehérje-expressziós profillal rendelkező CLL sejtpopuláció alakul ki [34, 42], amelyhez - elsősorban szöveti szinten - a különböző mikrokörnyezeti hatások szintén hozzájárulnak [52-55]. Az egyéb antiapoptotikus fehérjék (mint például az MCL1/BCL-XL) túlzott expressziója mellett az effektor proteinek szintjének csökkenése is megfigyelhető [42]. A protein expresszióban bekövetkező eltérések kópiaszám- vagy mRNS-szintü változásokkal asszociáltak. A venetoclax-rezisztencia kialakulásának multifaktoriális eredetét támasztja alá az a megfigyelés is, miszerint a BCL2-től eltérő antiapoptotikus proteinek túlzott expressziója gyakran jelenik meg BCL2 mutációt hordozó sejtpopulációban is [45, 48].

Az utóbbi időben egyre inkább a figyelem középpontjába kerülnek a venetoclax metabolikus hatásai, illetve ezen hatások potenciális rezisztenciát kiváltó képessége. A metabolikus reprogramming rezisztenciában betöltött szerepével kapcsolatban elsősorban az AMP-aktivált protein kinázt lehet kiemelni (adenozin monofoszfát aktivált protein kináz, AMPK). Az AMPK a sejtenergia metaboliz- 
musának egy kulcsfontosságú szabályozó proteinje, amely többek közt az oxidatív foszforilációban is pozitív szabályozó szerepet tölt be [56]. Guièze és mtsai az AMPK és OXPHOS venetoclax-rezisztenciában betöltött szerepét vizsgálva, in vitro dorsomorphin (AMPK inhibitor), valamint oligomycin és antimycin (ETC, elektron transzport lánc gátlók) adagolása mellett a venetoclax érzékenység emelkedését tapasztalták valamennyi vizsgált CLL minta esetében. Ezen felül ennek a három komponensnek a jelenlétében a rezisztens klónok venetoclax érzékenységének visszatérését figyelték meg. Egereken végzett in vivo kísérletek alapján az oligomycin és venetoclax kombináció hatásosabbnak bizonyult, mint a venetoclax monoterápia [39]. A rendelkezésre álló in vitro és in vivo adatok alapján egyértelmünek tünik a metabolikus reprogramming, az AMPK, illetve az OXPHOS szerepe a venetoclax-rezisztencia kialakulásában.

\section{A venetoclax-rezisztenciával társuló genetikai eltérések kimutatása}

Progresszió során más malignus hematológiai kórképekhez hasonlóan CLL-ben is genetikai változások jelenhetnek meg, melyek változatos genotípust kölcsönözhetnek a leukémiás sejtpopulációnak [57]. Célzott terápia alkalmazásával a különböző mikrokörnyezeti hatások következtében az egyes szubklónokban kifejlődő rezisztenciamutációk, vagy a már kezelés megkezdése előtt jelen lévő driver mutációk szelekciós előnyhöz juttatva egyes sejtpopulációkat tovább fokozhatják a sokrétü molekuláris megjelenést, elágazó szubklonális mintázatot létrehozva [48, 49, 58]. A rezisztens klónok gyakran egy vagy akár több, a rezisztencia kialakulásában kulcsszerepet játszó pontmutációt is hordoznak, amelyek érzékeny molekuláris diagnosztikai módszerekkel, akár hónapokkal a klinikai progresszió előtt kimutathatóak [45, 59, 60]. Blombery és mtsai a venetoclax-rezisztenciában leggyakrabban leírt G101V mutációt magas szenzitivitású digitális droplet PCR (ddPCR) technikával egyes esetekben 25 hónappal a klinikai progresszió előtt is képesek voltak kimutatni [45]. Hasonlóan, Tausch és mtsai egy retrospektív vizsgálat során háromból két G101V mutációt hordozó beteg esetében egy évvel azelőtt képesek voltak kimutatni a mutációt, hogy terápiaváltást kellett volna eszközölni [33]. A rezisztencia hátterében álló mutációk korai kimutatásának lehetősége arra enged következtetni, hogy megfelelő érzékenységű módszert alkalmazva az eltérések detektálása már hónapokkal előre jelezheti a klinikai progresszió kialakulását. Mindezt figyelembe véve a megfelelő érzékenységű mutációanalízis egy lehetséges monitorozási stratégia alapját képezheti a jövőben.

A betegek megfelelő monitorozásának és szürésének feltétele az elsősorban PCR vagy szekvenálási eljárásokon alapuló mutációanalízis. A két módszer eltérő alkalmazási profillal rendelkezik. A ddPCR viszonylag gyorsan kivitelezhető, nagyon magas érzékenység $(0,01 \%)$ és kvantita- tív megbízhatóság jellemzi, ezáltal ideális az alacsony VAF-fal rendelkező mutációk korai kimutatására [61, 62]. Ugyanakkor a ddPCR hátránya, hogy csak ismert mutációk azonosíthatóak vele, valamint magas a fajlagos költség. A szekvenálási eljárások közül elsősorban az NGS szerepét érdemes kiemelni a venetoclax-rezisztencia hátterében álló genetikai eltérések kimutatásában. A hagyományos Sanger-szekvenálás az erősen limitált, 20\% körüli szenzitivitása miatt nem alkalmas a gyakran alacsony arányban megjelenő mutációk detektálására. Az NGS a Sanger-szekvenálásnál magasabb érzékenységű, kiterjedt, egymástól akár távol elhelyezkedő genomikus régiók vizsgálatát is lehetővé tevő eljárás, amely tekintve a rezisztencia hátterében álló változatos genetikai eltéréseket, jól alkalmazható módszernek tünik a venetoclax kezelésben részesülő CLL-es betegek vizsgálatához. Széles körű alkalmazásának költsége, speciális műszerigénye, valamint a kapcsolódó bioinformatikai analízis szükségessége szabhat határt $[63,64]$. A venetoclax-rezisztenciával leggyakrabban asszociált G101V mutáció az esetek 50\%-ában detektálható progresszív CLL esetében [33, 45], így a monitorozási stratégia egyik sarokkövét képezheti a közeljövőben.

\section{Kezelési lehetőségek és terápiás kihívások venetoclax-rezisztencia esetében}

A venetoclax-rezisztenciával rendelkező, progrediáló betegek kezelésére jelenleg még nem elérhető egységes terápiás protokoll. Annak ellenére, hogy több potenciális alternatíva is felmerül, például BTK inhibitorok, CAR-T terápia vagy új BH3-mimetikumok alkalmazása, a prospektív klinikai adatok hiánya nagy kihívást jelent a megfelelő kezelés kiválasztásában.

Ígéretes lehetőségnek tűnik egy, az apoptotikustól eltérő útvonal gátlása. A BCR jelátviteli útvonalat gátló BTK inhibitor ibrutinib vagy zanubrutinib hatásos terápiás lehetőséget nyújthat a magas rizikójú, venetoclaxrezisztens, hasonló terápiában korábban nem részesülő betegek esetében [65-67]. A BTK gátlók hatásosnak bizonyultak Richter-transzformáció, valamint BCL2 G101V mutációt hordozó betegeknél egyaránt [66]. Továbbá a BTK gátlóknak fontos szerepük lehet a venetoclax-rezisztencia kialakulásának megakadályozásában is. Lucas és mtsai ibrutinib előkezelt, venetoclax terápiában részesülő betegpopulációt vizsgálva a BCL2 mellett az ibrutinibrezisztenciával társuló $B T K$, valamint $P L C G 2$ mutációkat hordozó szubklónok felszaporodását figyelték meg venetoclax-rezisztencia során. Ez a jelenség a BCR jelátviteli útvonal gátlók, valamint a BCL2 inhibitorok kombinációjának potenciális rezisztenciát megelőző hatására hívják fel a figyelmet [49].

Alternatív megoldást nyújthatnak az egyéb, venetoclaxtól eltérő BH3 mimetikumok. Ez a lehetőség elsősorban a BCL-2-től eltérő antiapoptotikus proteinek túlzott expressziója által előidézett rezisztencia esetén merül fel. 
Egy új funkcionális vizsgálat, az úgynevezett $\mathrm{BH}$-profilalkotás lehetőséget nyújt a BCL2 család tagjai közötti interakciók felderítésére, ezáltal egy személyre szabott BH3 mimetikus terápiás terv létrehozására [68]. Az MCL1 túlzott expresszióját többször is leírták venetoclax-rezisztens esetekben, amely indokolta egy szelektív inhibitor kifejlesztését. Az elmúlt időszakban három közvetlen MCL-1 gátló jelent meg, az AZD5991, AMG176, valamint a MIK665, amelyek a preklinikai adatok alapján ígéretes terápiás alternatívát jelenthetnek a jövőben [69, $70]$.

Bizonyos mikrokörnyezeti hatások a BCR jelátviteli útvonal fokozott stimulációjához vezetnek, ami hozzájárul a BCL2 proteinek diszregulációjához, valamint a rezisztencia kialakulásához [52]. A BCR jelátviteli útvonal aktivációjával párhuzamosan a foszfoinozitid-3 kináz/protein kináz B (PI3K/PKB) - Akt tengely szintén aktiválódik, amely számos túlélést befolyásoló útvonallal áll kapcsolatban, mint például a MAPK kaszkád, a nukleáris faktor kappa B vagy a nuclear factor of activated T-cells (NFAT) útvonalak. Ennek megfelelően a PI3K-gátló idelalisib egy elméleti terápiás lehetőséget jelenthet venetoclax-rezisztencia esetében.

A venetoclax-rezisztencia leküzdésében a fent említett lehetőségek mellett számos további ígéretes terápiás opció áll rendelkezésre, úgymint a különböző antitest célpontok (ROR-1, CD19, CD37), kiméra antigén receptor T-sejtterápia vagy az allogén őssejt-transzplantáció, bár ezen terápiás modalitások mindennapi klinikai gyakorlatba ültetése jelenleg is folyamatban van.

\section{Összefoglalás}

A venetoclax az első szelektív BCL-2 gátló antiapoptotikus szer, amely kiválóan alkalmazható a kedvezőtlen prognózisú, CLL-es betegpopulációban, a TP53 aberráció jelenlététől függetlenül. A látványos klinikai sikerek mellett a betegek egy részében terápiás rezisztencia alakul ki. A rendelkezésre álló irodalmi adatok alapján valószínüsíthető, hogy a rezisztencia hátterében több, heterogén, együttesen klinikailag relapszusban megnyilvánuló mechanizmus áll. A molekuláris diagnosztika az elmúlt években bekövetkezett robbanásszerű fejlődésének köszönhetően lehetőségünk adódott ezen mechanizmusok feltérképezésére, valamint potenciális áthidalására. A magas érzékenységű molekuláris vizsgálómódszerek lehetővé teszik a rezisztenciát okozó genetikai eltérések korai felismerését, lehetőséget biztosítva a klinikai relapszust megelőző, célzott terápiás váltás alapos megtervezésére. Egy molekuláris követésen alapuló, célzott kezelési stratégia létrejöttéhez elengedhetetlen egy megfelelő monitorozási és ehhez illeszkedő mintavételi protokoll létrehozása. Munkacsoportunk kiemelt figyelmet fordít a magyarországi venetoclax kezelésben részesülő betegek molekuláris követésére, a rezisztencia kialakulásának hátterében álló potenciális mechanizmusok felderítésére, valamint egy, a jövőben klinikai gyakorlatba ültethető monitorozási protokoll kidolgozására.

Nyilatkozat: A cikk nem jelent meg más folyóiratban és nem áll publikáció alatt. A levelező szerző a szerzői útmutatót elolvasta.

Érdekeltségek: A szerzőknek nincsenek érdekeltségeik. Anyagi támogatás: A közlemény az EU Horizon $2020 \mathrm{Ku}-$ tatási és Innovációs Programjának (739593), az MTA Bolyai János Ösztöndíj programjának (BO/00320/18/5), a Nemzeti Kutatási, Fejlesztési és Innovációs Hivatal FK20_134253 és K21 137948 pályázatainak, az Innovációs és Technológiai Minisztérium ÚNKP-20-5-SE-22, ÚNKP21-2-I-SE-21-KL kódszámú Új Nemzeti Kiválóság Program pályázatának, az ELIXIR Magyarországnak, valamint a Semmelweis Egyetem Kiegészítő Kutatási Kiválósági Ösztöndíjának (EFOP-3.6.3-VEKOP-16-2017-00009) és a Hungarian Centre of Excellence for Molecular Medicine (H2020-739593) támogatásával készült.

Szerzői munkamegosztás: Valamennyi szerző részt vett a közlemény megírásában, valamint az irodalmi adatok feldolgozásában. A cikk végleges változatát valamennyi szerző elolvasta és jóváhagyta.

\section{Irodalom}

[1] Landau DA, Tausch E, Taylor-Weiner AN, et al. Mutations driving CLL and their evolution in progression and relapse. Nature 2015; 526: 525-530.

[2] Oppezzo P, Dighiero G. Role of the B-cell receptor and the micro-environment in chronic lymphocytic leukemia. Blood Cancer Journal 2013; 3: 1-9.

[3] Kiss R, Alpár D, Gángó A, et al. Spatial clonal evolution leading to ibrutinib resistance and disease progression in chronic lymphocytic leukemia. 2019; e38-e41.

[4] Baliakas P, Jeromin S, Iskas M, et al. Cytogenetic complexity in chronic lymphocytic leukemia: definitions, associations, and clinical impact. Blood 2019; 133: 1205-1216.

[5] Chen C, Puvvada S. Prognostic Factors for Chronic Lymphocytic Leukemia. Curr Hematol Malig Rep. 2016; 11: 37-42.

[6] Eichhorst B, Hallek M. Prognostication of chronic lymphocytic leukemia in the era of new agents. Hematology Am Soc Hematol Educ Program 2016; 2016: 149-155.

[7] Takács F, Kardos I, Czeti Á, et al. A minimális reziduális betegség vizsgálata krónikus limfoid leukémiában. Hematológia-Transzfuziológia 2020; 53: 17-22.

[8] Rai KR, Sawitsky A, Cronkite EP, et al. Clinical staging of chronic lymphocytic leukemia. Blood 1975; 46: 219-234.

[9] Binet JL, Auquier A, Dighiero G, et al. A new prognostic classification of chronic lymphocytic leukemia derived from a multivariate survival analysis. Cancer 1981; 48: 198-206.

[10] Cramer P, Hallek M. Prognostic factors in chronic lymphocytic leukemia-what do we need to know? Nature Reviews Clinical Oncology 2011; 8: 38-47.

[11] Visentin A, Facco M, Gurrieri C, et al. Prognostic and Predictive Effect of IGHV Mutational Status and Load in Chronic Lymphocytic Leukemia: Focus on FCR and BR Treatments. Clinical Lymphoma, Myeloma \& Leukemia 2019; 19: 678-685.e674.

[12] Hallek, M. Chronic lymphocytic leukemia: 2020 update on diagnosis, risk stratification and treatment. American Journal of Hematology 2019; 94: 1266-1287.

[13] Wierda WG, Tambaro FP. How I manage CLL with venetoclax-based treatments. Blood 2020; 135: 1421-1427. 
[14] Agency EM. An overview of Venclyxto and why it is authorised in the EU. 2016.

[15] Coutre S, Choi M, Furman RR, et al. Venetoclax for patients with chronic lymphocytic leukemia who progressed during or after idelalisib therapy. Blood 2018; 131: 1704-1711.

[16] Jones JA, Mato AR, Wierda WG, et al. Venetoclax for chronic lymphocytic leukaemia progressing after ibrutinib: an interim analysis of a multicentre, open-label, phase 2 trial. The Lancet Oncology. 2018; 19: 65-75.

[17] Roberts AW, Davids MS, Pagel JM, et al. Targeting BCL2 with Venetoclax in Relapsed Chronic Lymphocytic Leukemia. The New England Journal of Medicine. 2016; 374: 311-322.

[18] Stilgenbauer S, Eichhorst B, Schetelig J, et al. Venetoclax in relapsed or refractory chronic lymphocytic leukaemia with $17 \mathrm{p} \mathrm{de}-$ letion: a multicentre, open-label, phase 2 study. The Lancet. Oncology 2016; 17: 768-778.

[19] Seymour JF, Kipps TJ, Eichhorst B, et al. Venetoclax-Rituximab in Relapsed or Refractory Chronic Lymphocytic Leukemia. New England Journal of Medicine 2018; 378: 1107-1120.

[20] Seymour JF, Ma S, Brander DM, et al. Venetoclax plus rituximab in relapsed or refractory chronic lymphocytic leukaemia: a phase 1b study. The Lancet. Oncology 2017; 18: 230-240.

[21] Fischer K, Al-Sawaf O, Bahlo J, et al. Effect of fixed-duration venetoclax plus obinutuzumab (VenG) on progression-free survival (PFS), and rates and duration of minimal residual disease negativity (MRD-) in previously untreated patients (pts) with chronic lymphocytic leukemia (CLL) and comorb. Journal of Clinical Oncology 2019; 37: 7502-7502.

[22] Fischer K, Sawaf OA, Bahlo J, et al. Venetoclax and Obinutuzum$\mathrm{ab}$ in Patients with CLL and Coexisting Conditions. 2019.

[23] Othman Al-Sawaf CZ, et al. Fixed-duration venetoclax-obinutuzumab for previously untreated chronic lymphocytic leukemia: follow-up of efficacy and safety results from the multicenter, open-label, randomized phase 3 cll14 trial [ABSTRACT]. 25th EHA Congress. 2020; S155.

[24] Cimmino A, Calin GA, Fabbri M, et al. miR-15 and miR-16 induce apoptosis by targeting BCL2. Proceedings of the National Academy of Sciences of the United States of America 2005; 102: 13944 13949.

[25] Del Gaizo Moore V, Brown JR, Certo M, et al. Chronic lymphocytic leukemia requires BCL2 to sequester prodeath BIM, explaining sensitivity to BCL2 antagonist ABT-737. The Journal of Clinical Investigation 2007; 117: 112-121.

[26] Robertson LE, Plunkett W, McConnell K, et al. Bcl-2 expression in chronic lymphocytic leukemia and its correlation with the induction of apoptosis and clinical outcome. Leukemia 1996; 10: 456-459.

[27] Lampson BL, Davids MS. The Development and Current Use of BCL-2 Inhibitors for the Treatment of Chronic Lymphocytic Leukemia. Current Hematologic Malignancy Reports 2017; 12: 11-19.

[28] Shamas-Din A, Brahmbhatt H, Leber B, et al. BH3-only proteins: Orchestrators of apoptosis. Biochimica et Biophysica Acta. 2011; 1813: 508-520.

[29] Fridman JS, Lowe SW. Control of apoptosis by p53. Oncogene. 2003; 22: 9030-9040.

[30] Cheng EH, Levine B, Boise LH, et al. Bax-independent inhibition of apoptosis by Bcl-XL. Nature 1996; 379: 554-556.

[31] Cheng EH, Wei MC, Weiler S, et al. BCL-2, BCL-X(L) sequester BH3 domain-only molecules preventing BAX- and BAK-mediated mitochondrial apoptosis. Molecular Cell 2001; 8: 705-711.

[32] Letai A, Bassik MC, Walensky LD, et al. Distinct BH3 domains either sensitize or activate mitochondrial apoptosis, serving as prototype cancer therapeutics. Cancer Cell 2002; 2: 183-192.

[33] Tausch E, Close W, Dolnik A, et al. Venetoclax resistance and acquired BCL2 mutations in chronic lymphocytic leukemia. Haematologica 2019; 104: e434-e437.
[34] Bose P, Gandhi V, Konopleva M. Pathways and mechanisms of venetoclax resistance. Leukemia \& Lymphoma 2017; 58: 1-17.

[35] Mihalyova J, Jelinek T, Growkova K, et al. Venetoclax: A new wave in hematooncology. Experimental Hematology 2018; 61: $10-25$.

[36] Salem AH, Agarwal SK, Dunbar M, et al. Pharmacokinetics of Venetoclax, a Novel BCL-2 Inhibitor, in Patients With Relapsed or Refractory Chronic Lymphocytic Leukemia or Non-Hodgkin Lymphoma. Journal of Clinical Pharmacology 2017; 57: 484-492.

[37] Chen ZX, Pervaiz S. Bcl-2 induces pro-oxidant state by engaging mitochondrial respiration in tumor cells. Cell Death and Differentiation 2007; 14: 1617-1627.

[38] Lagadinou ED, Sach A, Callahan K, et al. BCL-2 inhibition targets oxidative phosphorylation and selectively eradicates quiescent human leukemia stem cells. Cell Stem Cell 2013; 12: 329-341.

[39] Guièze R, Liu VM, Rosebrock D, et al. Mitochondrial Reprogramming Underlies Resistance to BCL-2 Inhibition in Lymphoid Malignancies. Cancer Cell 2019; 36: 369-384.e313.

[40] Lucantoni F, Düssmann H, Llorente-Folch I, et al. BCL2 and $\mathrm{BCL}(\mathrm{X}) \mathrm{L}$ selective inhibitors decrease mitochondrial ATP production in breast cancer cells and are synthetically lethal when combined with 2-deoxy-D-glucose. Oncotarget. 2018; 9: 2604626063.

[41] Roca-Portoles A, Rodriguez-Blanco G, Sumpton D, et al. Venetoclax causes metabolic reprogramming independent of BCL-2 inhibition. Cell Death \& Disease 2020; 11: 616-616.

[42] Tahir SK, Smith ML, Hessler P, et al. Potential mechanisms of resistance to venetoclax and strategies to circumvent it. BMC Cancer 2017; 17: 399.

[43] Deng J, Carlson N, Takeyama K, et al. BH3 profiling identifies three distinct classes of apoptotic blocks to predict response to ABT-737 and conventional chemotherapeutic agents. Cancer Cell 2007; 12: 171-185.

[44] Anderson MA, Deng J, Seymour JF, et al. The BCL2 selective inhibitor venetoclax induces rapid onset apoptosis of CLL cells in patients via a TP53-independent mechanism. Blood 2016; 127: 3215-3224.

[45] Blombery P, Anderson MA, Gong JN, et al. Acquisition of the recurrent Gly101Val mutation in BCL2 confers resistance to venetoclax in patients with progressive chronic lymphocytic leukemia. Cancer Discovery 2019; 9: 342-353.

[46] Fresquet V, Rieger M, Carolis C, et al. Acquired mutations in BCL2 family proteins conferring resistance to the $\mathrm{BH} 3$ mimetic ABT-199 in lymphoma. Blood. 2014; 123: 4111-4119.

[47] Weiss J, Peifer M, Herling CD, et al. Acquisition of the recurrent Gly101Val mutation in BCL2 confers resistance to venetoclax in patients with progressive chronic lymphocytic leukemia (Comment to Tausch et al.). Haematologica 2019; 104: e540-e540.

[48] Blombery P, Thompson ER, Nguyen T, et al. Multiple BCL2 mutations cooccurring with Gly101Val emerge in chronic lymphocytic leukemia progression on venetoclax. Blood 2020; 135: 773777.

[49] Lucas F, Larkin K, Gregory CT, et al. Novel BCL2 mutations in venetoclax-resistant, ibrutinib-resistant CLL patients with BTK/ PLCG2 mutations. Blood 2020; 135: 2192-2195.

[50] Daniela Steinbrecher FS, Eugen Tausch, et al. Mechanisms conferring resistance to venetoclax in chronic lymphocytic leukemia and mantle cell lymphoma [ABSTRACT]. 25th EHA Congress. 2020; EP662.

[51] Takács F, Mikala G, Nagy N, et al. Identification of a novel resistance mechanism in venetoclax treatment and its prediction in chronic lymphocytic leukemia. Acta Oncol. 2021; 60: 528-530.

[52] Bojarczuk K, Sasi BK, Gobessi S, et al. BCR signaling inhibitors differ in their ability to overcome Mcl-1-mediated resistance of CLL B cells to ABT-199. Blood 2016; 127: 3192-3201.

[53] Kater AP, Evers LM, Remmerswaal EBM, et al. CD40 stimulation of B-cell chronic lymphocytic leukaemia cells enhances the anti-apoptotic profile, but also Bid expression and cells remain sus- 
ceptible to autologous cytotoxic T-lymphocyte attack. British Journal of Haematology 2004; 127: 404-415.

[54] Petlickovski A, Laurenti L, Li X, et al. Sustained signaling through the B-cell receptor induces Mcl-1 and promotes survival of chronic lymphocytic leukemia B cells. Blood 2005; 105: 4820-4827.

[55] Smit LA, Hallaert DY, Spijker R, et al. Differential Noxa/Mcl-1 balance in peripheral versus lymph node chronic lymphocytic leukemia cells correlates with survival capacity. Blood 2007; 109: $1660-1668$.

[56] Arroyo JD, Jourdain AA, Calvo SE, et al. A Genome-wide CRISPR Death Screen Identifies Genes Essential for Oxidative Phosphorylation. Cell metabolism. 2016; 24: 875-885.

[57] Fabbri G, Dalla-Favera R. The molecular pathogenesis of chronic lymphocytic leukaemia. Nat Rev Cancer 2016; 16: 145-162.

[58] Herling CD, Abedpour N, Weiss J, et al. Clonal dynamics towards the development of venetoclax resistance in chronic lymphocytic leukemia. Nature Communications 2018; 9: 727.

[59] Woyach JA, Ruppert AS, Guinn D, et al. BTK(C481S)-Mediated Resistance to Ibrutinib in Chronic Lymphocytic Leukemia. J Clin Oncol. 2017; 35: 1437-1443.

[60] Bödör C, Kotmayer L, László T, et al. Screening and monitoring of the BTKC481S mutation in a real-world cohort of patients with relapsed/refractory chronic lymphocytic leukaemia during ibrutinib therapy. Br J Haematol. 2021; 194: 355-364.

[61] Milbury CA, Zhong Q, Lin J, et al. Determining lower limits of detection of digital PCR assays for cancer-related gene mutations. Biomolecular Detection and Quantification. 2014; 1: 8-22.

[62] Frazzi R, Bizzarri V, Albertazzi L, et al. Droplet digital PCR is a sensitive tool for the detection of TP53 deletions and point muta- tions in chronic lymphocytic leukaemia. British Journal of Haematology 2020; 189: e49-e52.

[63] Aczél D, Mátrai Z, Kiss R, et al. Ibrutinibrezisztencia krónikus limfocitás leukémiában. 2019; 52: 136.

[64] Tan O, Shrestha R, Cunich M, et al. Application of next-generation sequencing to improve cancer management: A review of the clinical effectiveness and cost-effectiveness. Clin Genet. 2018; 93: 533-544.

[65] Greil R, Fraser G, Leber B, et al. Efficacy and Safety of Ibrutinib (IBR) after Venetoclax (VEN) Treatment in IBR-Naïve Patients with Relapsed/Refractory (R/R) Chronic Lymphocytic Leukemia (CLL): Follow-up of Patients from the MURANO Study. Blood 2018; 132: 5548-5548.

[66] Lin VS, Lew TE, Handunnetti SM, et al. BTK inhibitor therapy is effective in patients with CLL resistant to venetoclax. Blood 2020; 135: 2266-2270.

[67] Brown JR, Davids MS, Chang J, et al. Outcomes of Ibrutinib Therapy Given after Prior Venetoclax Therapy in Ibrutinib-Naïve Patients with Relapsed/Refractory (R/R) Chronic Lymphocytic Leukemia (CLL). Blood 2018; 132: 5556-5556.

[68] Valentin R, Grabow S, and Davids MS The rise of apoptosis: targeting apoptosis in hematologic malignancies. Blood 2018; 132: 1248-1264.

[69] Hird AW, Tron AE. Recent advances in the development of Mcl-1 inhibitors for cancer therapy. Pharmacology \& Therapeutics 2019; 198: 59-67.

[70] Xiang W, Yang C-Y, Bai L. MCL-1 inhibition in cancer treatment. Onco Targets Ther. 2018; 11: 7301-7314.

A cikk a Creative Commons Attribution 4.0 International License (https://creativecommons.org/licenses/by/4.0/) feltételei szerint publikált Open Access közlemény, melynek szellemében a cikk bármilyen médiumban szabadon felhasználható, megosztható és újraközölhető, feltéve, hogy az eredeti szerző és a közlés helye, illetve a CC License linkje és az esetlegesen végrehajtott módosítások feltüntetésre kerülnek. (SID_1) 